\title{
Mevsimsel olarak merada yetiştirilen koyunlarda serum bakır, çinko ve seruloplazmin düzeyleri ile yün bakır ve çinko değerlerinin araştırılması*
}

\author{
Suat ERDOĞAN ${ }^{1}$, Zeynep ERDOĞAN², Nurhan ŞAHİN ${ }^{3}$ \\ 'Mustafa Kemal Üniversitesi, Veteriner Fakültesi, Biyokimya Anabilim Dalı, Hatay; 2Mustała Kemal Üniversitesi, Hayvan Besleme \\ ve Beslenme Hastalıkları Anabilim Dalı, Hatay; ${ }^{3}$ Veteriner Kontrol ve Araştırma Enstitiisü. Elazı
}

Özet: Hatay bölgesinde Mart-Haziran dönemlerinde mera şartlarında yetiştirilen, ilave yem verilmeyen ve klinik olarak să̆ lıklı görïnen koyunlarda bakir ve çinko değerleri serum ve yün örneklerinde; seruloplazmin düizeyleri ise serumda araştırıldı. Mineral madde analizleri atomik absorbsiyon spektrofotometrede, seruloplazmin düzeyleri spektrofotometrede ölçïldui. Ortalama serum bakır

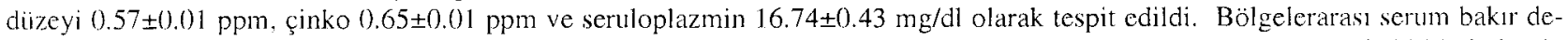
ğerleri arasunda istatistiksel fark bulunmazken $(p>0.10)$; çinko ve seruloplazmin değgerleri yöniinden önemli farklılı bulundu $(p<() .(x) 1)$. Seruloplazmin ile scrum bakır deฮ̆gerleri arasında pozitif zayıf derecede bir ilişkinin olduğti görüldij. Ortalatna yün bakır değeri 4.40土(0.24 ppm ve çinko dïzeyi $48.51 \pm 2.26 \mathrm{ppm}$ olarak saptandı. Bölgeler arasında yün bakır ve çinko değerleri yönünden anlamlı fark bulunmadı $(\mathrm{p}>0$ ).10). Hatay bölgesi koyunlarında yün ve serum bakır düzeyinin kritik sınıra yakın; çinkonun ise normal değ erlerden diişüik olduğu saptand. Meraya dayah beslemenin yapıldığı dönemde hayvanlara mineral takviyelerinin yapılması gerekliğ sonucuna varıldı.

Anahtar kelimeler: Bakır, çinko, seruloplazmin, serum, yïn

An investigation of copper, zinc, ceruloplasmin levels in serum, copper and zinc levels in wool samples of seasonal grazing sheep

Summary: Copper and zinc levels were determined in serum and wool samples, ceruloplasmin level was determined in serum. The samples were collected from clinically healty, grazing sheep between March-June in Hatay region. Additional feed was not given to sheep during this season. Mineral levels were analysed by atomic absorption spectrophotometry, ceruloplasmin levels were measured by spectrophotometry. Mean serum copper, zinc and ceruloplasmin levels were $0.57 \pm(0.01 \mathrm{ppm} .(0.65 \pm 0.01 \mathrm{ppm}$, $16.74 \pm 0.43 \mathrm{ppm}$, respectively. Although there was no statistically significancy between serum $\mathrm{Cu}$ levels of the regional sheep $(p>0.1(0)$, there was significancy between serum zinc and ceruloplasmin levels of the regional sheep ( $p<0.01)$. Mean wool copper and zinc levels were 4.4()$\pm 0.24 \mathrm{ppm}, 48.51 \pm 2.26 \mathrm{ppm}$, respectively. A positive but weak correlation was determined between serum ceruloplasmin and copper levels. However, there was no correlation between neither serum and wool copper levels nor serum and wool zinc levels were detected. In wool, copper and zinc levels of the regional sheep were not varied between the regions $(p>0)$. 10$)$. It is concluded that serum and wool copper levels were determined close to the critical level, zinc levels were found to be under the normal level. Mineral supplementation to seasonal grazing animals should be considered in this region.

Key words: Ceruloplasmin, copper,serum, wool, zinc

\section{Giriş}

Insan ve hayvan vücudunda eser düzeyde bulunan bakır, hücresel solunumda görev yapan sitokrom $c$ oksidaz, süperoksit dismutaz, tirozinaz ve dopamin $\beta$ hidroksilaz gibi bazı metalloenzimlerin yapısma girer (9,19). Plazma bakırının yaklaşık \%90-95'i $\alpha_{2}$-globuline bağlı olarak seruloplazmin şeklinde bulunur $(9,19)$. Plazma bakır seviyesini etkileyen faktörler seruloplazmin dïzeyini de etkiler. Bakır, sinir hüicreleri tarafından salglanan ve hücre yüzeyi glikoproteini olan prion proteini (PrPc) yapısinda da yer alır (7). Prion proteini superoksit dismutaz benzeri bir antioksidan etkiye sahip olup, oksidatif strese karşı hücrenin kendini korumasında yardımcı olur (41). Bu proteinin yapısında oluşan bozukluk lara bağlı olarak, sinir huicrelerinde dejeneratif bozukluklar ve hüicre ölümleri şekillenir (7).

Koyunlarda bakır noksanlıkları sonucu büyimede yavaşlama, zayıflama, fertilite kaybı, anemi, ishal, kıl ve yapağı kalitesi ve pigmentasyonda bozukluklar, süt emen kuzularda enzootik ataksi sonucu parezis ve ölüm şekillenir $(2,28,29)$. Hastalık belirtileri subklinik veya klinik düzeyde seyredebilir (18).

* Bu araştırma Mustafa Kemal Unniversitesi Araştırma Fonu tarafundan desteklenmiştir (Proje no: 01G (0401) 
Çinko, karbonik anhidraz, alkalen fosfataz, RNA ve DNA polimeraz, alkol dehidrojenaz gibi önemli metalloenzimlerin yapısında ve fonksiyonunda görev alır (9). Ayrıca, yapısında $\mathrm{Zn}^{2+}$ atomu bulunduran çinko parmak proteinleri (zinc finger proteins) DNA molekuilü üzerinde özgïn bölgelere bağlanarak gen ekspresyonunun kontrolü ve dolayisıyla protein sentezi ve metabolizmasinda esansiyel bir elementtir (6). Çinko yetersizliklerinde hayvanlarda iştah kaybı, gelişme geriliğgi, fertilite dưşüklüğü ve deri lezyonları ortaya çıkar $(14,19,27)$.

Hayvanlarda bakır ve çinko düzeyi toprağın bileşimi, iklim şartları, hasat işlemleri, mera ve rasyonların bu elementlerden fakir olması, bakır ve çinkonun birbirleriyle ve molibden, kurşun, kadmiyum ve kükürt gibi bazı elementler ile antagonistik etkileşimleri, gebelik, mevsim ve genetik faktörler etkili olmaktadır $(1,17,35$, 37,39).

Hayvansal dokulardaki mineral madde dïzeylerinin belirlenmesinde serumdan ve yün, kıl, karaciğger ve böbrek gibi dokulardan yararlanılmaktadır. Ancak, hayvanlarda doku, k1l veya yün mineral diizeylerinin ölçümii serum analizlerine göre daha doğru sonuçlar verdiğ bildirilmektedir (5). Ayrıca, seruloplazmin dïzeyi ölçümlerinin hayvandaki bakır düzeyi hakkında fikir vereceği rapor edilmektedir (9).

Hatay bö]gesinde koyun yetiştiriciliği, mera vejetasyonunun uygun olduğu Mart-Haziran başlangıcı dönemleri ile vejetasyonun yetersiz bulunduğu Ağustos ayı başlarmna kadar ilave yem verilmeksizin mera şartlarında yapılmakıadır. Bu araştırmada, vejetasyon dönemi ve sonrası tamamen meraya dayalı yetiştiriciliğin hayvanlarda oluşturabileceği bakır ve çinko yetersizlikleri araştrrıldı. Bu amaçla, serum ve yün örneklerinde bakır ve çinko düzeyleri ile serumda seruloplazmin düzeyleri tespit edildi.

\section{Materyal ve Metot}

Bu araştırmanın materyalini, Reyhanl, Alunözii, Hassa, Kırkhan, Antakya ve Şenköy ilçelerị ile bunlara bağlı köylerde yetiştirilen klinik olarak sağ çoğunluğu Dağlıç, az sayıda tvesi ırkı 195 adet 1-4 yaşh koyun oluşturdu. Hayvanlar, mera vejetasyonin uygun olduğu Mart-Haziran ayı başlanğı̧̣ döneminde merada; Haziran ayı sonuna kadar ise tahıl hasatı bitibininde açılan alanlarda ilave yem verilmeden beslenmekteydi. Tenmuz-Ağustos 2001 tarihlerinde, bölge koyuhlarmı temsil edecek şekilde 195 koyunun vena jugularis lerinden kan ve 60 koyunun boyun bölgelerinden yün örnekleri alındı. Hemolizsiz serumlardan spektrofotometrik yöntemle aynı giin seruloplazmin analizleri yapıldı (10). Bjakır ve çinko düzeylerinin belirlenmesi için serumlar analize kadar $-22^{\circ} \mathrm{C}$ 'de muhafaza edildi. Serum (30) ve yiun (33) bakır ve çinko dïzeyleri Shimadzu-660 alomik absorbsiyon spektrofotometrik yöntemle belirlendi. Veriller SPSS 9.05 paket programında tek yönlii varyans analizi ve Duncan testi uygulanarak değerlendirildi (32).

\section{Bulgular}

Kan ve yün örnekleri alınan koyunlarda yapılan klinik muayenelerde, bazı hayvanlarda yuinlęrde kabalaşma ve koyu renkli yünlerde renk açılmaları tespil edildi. Yetiştiricilerden alınan ifadelere göre, hayvanlarda kilo alamama ve sürilerde gebe kalma orannda dijşüklikk gibi şikayetler vardı. Bölgelere göre koyunlarıh serum bakır, çinko ve seruloplazmin dizeyleri ile yüin bakır ve çinko değerleri Tablo 1'de, bu değerlerin yüzz̧亻 olarak dağllımları ise Tablo 2'de gösterilmiştir.

Tablo 1. Sağ|ıklı koyunlarda kan serumu bakır (ppm), çinko (ppm), seruloplazmin (mg/dl); yün bakır (ppm) ve çink değerleri.

Table 1. Mean blood serum copper, zinc (ppm) and ceruloplasmin (mg/dl), wool copper and zinc (ppm) lcvels in heally sheep

\begin{tabular}{|c|c|c|c|c|c|c|c|}
\hline & \multicolumn{4}{|c|}{ Serum } & \multicolumn{3}{|c|}{ Yün } \\
\hline & & $\mathrm{Cu}$ & $\mathrm{Zn}$ & Seruloplazmin & & $\mathrm{Cu}$ & $\mathrm{Zn}$ \\
\hline Bölge & $n$ & $x \pm S x$ & $x \pm S x$ & $x \pm S x$ & $n$ & $\mathrm{x} \pm \mathrm{Sx}$ & $x \pm S x$ \\
\hline Reyhanlı & 36 & $0.54 \pm 0.04$ & $0.70 \pm 0 .\left(12^{\mathrm{c}}\right.$ & $21.08 \pm 1.20^{\mathrm{c}}$ & 10 & $5.40 \pm 0.34$ & $46.17 \pm 3.50$ \\
\hline Altınözii & 21 & $0.56 \pm 0.02$ & $0.73 \pm 0.07^{d}$ & $21.12 \pm\left(1.93^{\circ}\right.$ & 10 & $5.43 \pm 1.59$ & $63.03 \pm 3.51$ \\
\hline Hassa & 51 & $0.58 \pm 0.02$ & $0.57 \pm 0.02^{b}$ & $15.16 \pm\left(0.56^{\mathrm{ab}}\right.$ & 10) & $4.07 \pm 0.16$ & $48.49 \pm 5.11$ \\
\hline Kurikhan & 17 & $0.65 \pm 0.04$ & $0.36 \pm 0.02^{\mathrm{a}}$ & $17.65 \pm 1.39^{\mathrm{b}}$ & 10 & $3.14 \pm 0.21$ & $42.012 \pm 5.02$ \\
\hline Antakya & 20 & $0.52 \pm 0.03$ & $0.80 \pm 0.03^{d}$ & $17.18 \pm 1.11^{\mathrm{b}}$ & 10 & $4.41 \pm 1.24$ & $56.70 \pm 4.78$ \\
\hline Şenköy & 50 & $0.60 \pm 0.02$ & $0.74 \pm 0.02^{\mathrm{cd}}$ & $13.79 \pm\left(0.70^{\mathrm{a}}\right.$ & 10 & $4.88 \pm 0.52$ & $60.68 \pm 1.76$ \\
\hline Ortalama & 195 & $0.57 \pm 0.01$ & $0.65 \pm 0.01$ & $16.74 \pm 0.43$ & 60 & $4.40 \pm(0.24$ & $48.51 \pm 2.26$ \\
\hline$p$ & & $>0.10$ & $<0.001$ & $<0.001$ & & $>0.10$ & $\geq 0.10$ \\
\hline
\end{tabular}


Tablo 2. Serum bakır, çinko ve seruloplazmin değerlerinin kritik sunır altında kalanlan yüzdesi.

Table 2. Serum copper, zinc and ceruloplasmin percentages that arc under the critical boundary.

\begin{tabular}{|c|c|c|c|}
\hline Bölge & $\begin{array}{c}\mathrm{Cu} \\
0.50 \mathrm{ppm} \text { den } \\
\text { diişiik }(\%)\end{array}$ & $\begin{array}{c}\mathrm{Zn} \\
0.80 \text { ppm'den } \\
\text { düşiik }(\%)\end{array}$ & $\begin{array}{c}\text { Seruloplazmin } \\
11 \mathrm{mg} / \mathrm{dl} \text { 'den } \\
\text { diişük }(\%)\end{array}$ \\
\hline Reyhanl & 50 & 75 & 3 \\
\hline Alunözzii & 10) & 77 & 0 \\
\hline Hassa & 30 & 96 & 26 \\
\hline Kirıkhan & 6 & 100 & 13 \\
\hline Antakya & 48 & 15 & 20 \\
\hline Şenköy & 30 & 72 & 38 \\
\hline Ortalama & 31 & 78 & 19 \\
\hline
\end{tabular}

\section{Tartışma ve Sonuç}

Araştırmaya alınan koyunların ortalama serum bakır diizeyleri $0.57 \pm 0.01 \mathrm{ppm}$ olarak tespit edilmiştir. Bu değerin, iki y1l önce benzer yörelerde yapılan bir araşturmada (13) elde edilen değerlerden $(0.32 \pm 0.01 \mathrm{ppm})$ daha yiiksek olduğu görülmüştür. Aradaki bu farklılık; yılın değişik dönemlerine, yağı gibi iklim şartlarına (40), hayvanlarm yaş, gebelik ve laktasyon gibi fizyolojik durumlarına bağlı olabileceği ile açiklanabilir (25). Bölgelere göre serum bakır duizeyleri arasında istatistik yönden bir fark bulunmamuşur ( $p>0.10)$. Ortalama serum bakır düzeyleri bölgelerde $0.52 \pm 0.03$ ile $0.65 \pm 0.04 \mathrm{ppm}$ arasında bir dağllım gösterniştir (Tablo 1). Hayvanların serum bakır düzeyleri Lorenz ve Gibb (24)'in bildirdiği ve kritik değer olarak kabul edilen 0.50 ppm'den biraz yuiksek olmakla birlikte; Kaneko (19), Lorenz ve Gibb (24) 0.60 ppm; Faye (16) ve Underwood (37) $0.80-1.20$ ppm; Kurt ve ark. (22)'nun bildirdikleri $1.26 \mathrm{ppm}$ değerlerinden daha düşük düzeyde saptanmıştır. Çalışmaya alman koyunlarm serum bakır dizeyleri bireysel olarak incelendiğinde, hayvanlar arasinda bölgelere göre \%6 ile \%50 oranında bakır noksanlı ğı varlı̆̆ı saptanmıştır (Tablo 2). Bu sonuçlara göre, hayvanlarm tipik klinik belirtiler göstermemesine rağmen, sürü içerisinde bireysel olarak subklinik bakır yetersizliğinin varlığ düşünülebilir.

Seruloplazmin seviyesinin belirlenmesi de hayvanlardaki bakır dizeyinin bilinmesinde önem taşmaktadır (9). Bu araşturmada, ortalama seruloplazmin seviyesi $16.74 \pm 0.43 \mathrm{mg} / \mathrm{dl}$ bulunmuştur. Bölgelere göre ise $13.79 \pm 0.70$ ile $21.12 \pm 0.93 \mathrm{mg} / \mathrm{dl}$ arasında bir dağılım göstermiş ve aralarında önemli derecede fark bulunmuştur $(p<0.01$; Tablo 1). Ortalama değer, Şahin (34)'in belirttiği $13.86 \pm 1.14 \mathrm{mg} / \mathrm{dl}$ ve Başpınar (4)' $\mathrm{n}$ bildirdiğ $16.11 \pm 1.22 \mathrm{mg} / \mathrm{dl}$ ile uyum gösterirken; Evans ve Wiederanders (15)'mn bulduğu $26.5 \mathrm{mg} / \mathrm{dl}$ düzeyinden daha düşüktür. Serpek ve ark. (31) Konya bölgesinde Dağlıç ırkında seruloplazmin seviyesini ortalama $11 \mathrm{mg} / \mathrm{dl}$ olarak belirlemişlerdir. Ivesi ve Dağlıç ırkları ïzerinde yapılan bu araştırmada, seruloplazmin dizzeyleri Serpek ve ark. (31)'nın bildirdiğ $11 \mathrm{mg} / \mathrm{dl}$ seviyesinden bölgelere göre $\% 0$ ile $\% 38$ orannnda düşiik bulummuştur (Tablo 2). Literatürde bildirilen değerler ile yapılan araştırma sonuçları arasındaki farklılık, bölgelerin toprak mineral bileşimi, iklim ve beslenme şartlarmdan kaynaklanabilir (9). Araşturmaya alınan hayvanların ortalama \%19'unda seruloplazmin, \%31'inde ise serum bakir diizeyinin bildirilen kritik değerlerden $(24,31)$ düşüik olduğu görülmüştür (Tablo 2). Serum bakır düzeyi ile seruloplazmin değerleri arasında yaplan korelasyon analizinde aralarında \%25.7 oranında pozitif fakat zayıf bir ilişki bulunmuştur.

Vücuttaki bakır ve çinko miktarların belirlemede k1] ve yün analizlerinin de önem taşıdı ğ $(5,11)$. Bu çalışmada, araştırmaya alınan koyunların yün ortalama bakır duizeyleri $4.40 \pm 0.24$ ppm olarak tespit edilmiştir. Sağlıklı koyunlardaki normal bakır düzeyi hakkında geniş aralıkiı değerler bildirilmektedir. Örneğin, Bayşu ve ark. (5) sağlıklı kuzularda yün bakır değerini 4.50 ppm; Altıntaş ve ark. (2) $4.87 \pm 1.35$ ve melezlerde 8.36 2.79 ppm; Kurt ve ark. (22) $7.76 \pm 1.11$ ppm; Burns ve ark. (8) 25 ppm olarak bildirmişlerdir. Lamand (23)'a göre ise kritik değer 7 ppm'dir. Hatay bölgesi koyunlarının yün bakır düzeylerinin kimi yazarlara $(2,5)$ göre normal kimine göre ise $(8,22,23)$ duişiik seviyede olduğu söylenebilir. Serum bakır düzeyleri ile yün bakır değerleri arasında bir ilişki bulunmamıştır.

Hayvansal dokularda bulunan çinko düzeyleri; bölge suları, toprak ve bitki örtüsüi mineral bileşiminden, rasyondaki çinko seviyesinden, hayvanın yaşı, $11 k$, fizyolojik durumu ve hastalık hallerinden etkilenmektedir (9,37). Yapılan araştırmalarda serum çinko diizeyleri 0.22 ppm (13); 0.27 ppm (29); 0.38-0.40 ppm (20); 0.89-1.05 ppm (2); 0.32-1.50 ppm (3); 1.13 ppm (22); $1.40 \mathrm{ppm}$ (21); 1.84 ppm (36) olarak bildirilmektedir. Bu çalışma$\mathrm{da}$, koyun scrumlarmın ortalama çinko düzeyi $0.65 \pm 0.01$ ppm; bölge ortalamaları ise $0.36 \pm 0.02$ ile $0.80 \pm 0.03 \mathrm{ppm}$ olarak saptanmış ve bölgeler arasında istatistiksel lark bulunmuştur $(p<0.001)$. Bu araştırmada tespit edilen ortalama değer Kaya ve ark. (20) ve Ozan (29)'nn bildirdiklerinden yuiksek, üstte belirtilen diğ ğer çalışmalardan ise duişuik duizeyde bulunmuştur. Bölgeler içerisinde serum çinko düzeyi en duişïk Kırıkhan $(0.36 \pm 0.02 \mathrm{ppm})$, en yüksek ise Antakya $(0.80 \pm 0.03)$ koyunlarnda bulunmuştur. Koyunlarda serum çinko diizeyi için kritik simır kabul edilen 0.80 ppm (16) seviyesine göre \% $15-100$ oranında çinko noksanlığı bulunduğu ortaya konmuştur (Tablo 2). Bu çalışmada elde edilen serum çinko değgeri, benzer bölgelerde iki yıl önce yapılan (13) çalışma sonuçlanna $(0.22 \pm 0.01 \mathrm{ppm})$ göre daha yiiksek diizeyde bu- 
lunmuştur. Bu sonuç, Wildeus (40)'un aynı bölge fakat farklı mevsimlerde serum ve doku mineral düzeylerinin değgişebileceğj bildirişi ile uyum içindedir.

Yün çinko değerlerinin hayvan vücudundaki çinko düzeyi hakkında önemli bilgiler verdiği bildirilmektedir (9). Koyunlarda yün çinko diizeyi 53.32 ppm (2); 98.75 ppm (22); 115 ppm (8) olarak bildirilmektedir. Yapilan bu araştrmada yün çinko ortalama düzeyi $48.51 \pm 2.26$ ppm olarak tespil edilmiş, bölgelere göre $42.02 \pm 5.02$ ile $63.03 \pm 3.51 \mathrm{ppm}$ düzeylerinde bir dağllım göstermiştir (Tablo 1). Saptanan ortalama değerin, Aluntaş (2) ve Burns (8)'ün bildirdiği değerlerden düşük olduğu göruilmektedir. Yapılan analizde yün çinko düzeyi ile serum çinko değerleri arasında bir ilişki bulunmamıştır. Bazı araşturmacllara göre serum ile yün çinko değerleri arasunda bir ilişki varken, bazılarına göre ise bu ilişki zayıf bulunmuştur $(26,38)$.

Toprak ve bitki mineral düzeyleri yönünden kapsamlı bir araştırmanın yapılmadığı Hatay bölgesinde, meraya dayalı yetiştirme dönemi sonrasında serum ve yün örneklerinde bakır ve çinko dïzeyleri araştırılmıştır. Araştırmaya alınan hayvanlarda bakır duizeyinin yetersizlik smmrnna yakın veya altında; çinko düzeyinin ise normálin alunda olduğu saptanmıştır. Bu dönemde meraya ilaveten hayvanlara bakır ve çinko takviyelerinin yapılması gerektiği söylenebilir. Bölge su kaynakları, toprak ve mera bitkileri mineral içeriklerinin belirlenmesinin bölge hayvancılığı için yararlı olacağı kanısına varılmıştir.

\section{Kaynaklar}

1. Alonso ML (2000): Arsenic, cadmium, lead. copper and zinc in cattle from Galicia. NW Spain. Sci Total Environ, 246. 237-248.

2. Altıntaş A, Uysal H, Yıldız S, Goncagül T (1990): Akkaraman ve melezlerinde serum ve yapağt örneklerinde karşlaş̧ımal mineral durumu. Lalahan Hay Araş Enst Derg, 30, 40)-56

3. Antaplı M (1990): Koyunlarm kanunda çinko seviyeleri ile karbonik anhidraz, aktiviteleri arasındaki iliskilerin araşturlmast. Doğga Tr J Vet Anim Sci, 14, 272-281.

4. Başpinar N (1989): Gebe koyunlarda vitamin C, seruloplazmin, glikoz. ve hemoglobin de gerlerinin postpartum ilk aya kadar de gisimleri ve bu parametreler arasundaki ilişkiler. Doktora Tezi. SÜ Să̋ Bil Enst, Konya.

5. Bayşu N, Dündar Y, Bayrak S (1984): Koyun ve kuzularda yiin ve kan bakır değerleri arasundaki iliski ve bunun diagnostik önemi. Doğa Bil Der, 8, 117 - 122.

6. Berg JM (1990): Zinc finger donains: Hypotheses and current knowledge. Ann Rev Biophys Chem, 19, 405-421.

7. Brown DR (2001). Copper and prion disease. Brain Res Bull, 55, 165-173.

8. Burns RH, Johnston A, Hamilton JW, McCollach RJ, Duncan We, Fisk HG (1964): Minerals in domestic wools. J Anim Sci, 23, 5-11.
9. Burtis CA, Ashwood ER (1999): Tietz, Textbook of Clinical Chemism: $3^{\text {rd }}$ Ed. WB Saunders Company. Philadelphia.

1

10. Colombo JP, Richterich R (1964): Zur bestimmung des caeruloplasmin im plasma. Schweiz Med Wschr. 94, 715 720.

11. Combs DK, Goodrich RD, Meiske JC (1982): Mineral concentrations in hair as indicator of mineral status. A review. J Anim Sci, 54, 391-398

12. Çimtay I (1999): Sı̆̆r; kovun ve keçilerde bakır yetersizliği ve önemi. T Vet Hek Dern Derg, 11, (15-20.

13. Erdoğan S, Ergün Y, Erdoğan Z, Konthş T (20)(2): Hatay bölgesinde merada yetiştirilen keyun ve keçi serunlarunda baza mineral madde dizeyleri. Tutk J Vet Anim Sci, 26, 177-182.

14. Ergün A (1983): Zinc metabolism and deficiency in domestic animals. Ankara Üniv Vet Fak Derg, 30. 308-316.

15. Evans GW, Wiederanders RE (1967): Blood copper variation among species. Amer J Physiol, 213, 183-1185.

16. Faye B, Kamil M, Labonne M (1990): Teneur en oligoelements dans les fourrages et le plasma dest ruminants domestiques en Republique de Djibouti. Rev Elev Med Vet Pays Trop, 43, 365-373. 17. Haenlein GFW (1980): Mineral nutrition of socts. J Dairy
Sci, $\mathbf{6 3}, 1729-1748$.

18. Howard JL (1986): Current Veterinary Therapy 2. Food Animal Practice. WB Saunders Company, Philadelphia.

19. Kaneko JJ, Harvey JW, Bruss ML (1997): Clinical Biochemistry of Domestic Animals. $5^{\text {th }}$ Ed. Alcademic Press. London.

20. Kaya N, Utlu N, Uyanık BS, Özan A (1998): The serum zinc and copper values of the Morkaraman and Tuj sheep grown up in the pasture conditions in and around Kars. $\mathrm{Tr}$ J Vet Anim Sci, 22, 399-402.

21. Kirk DJ, Greene LW, Schelling GT, Byres FM (1985): Effect of monensin on $\mathrm{Mg}, \mathrm{Ca}, \mathrm{P}$ and Zn metabolism and tissue concentrations in lambs. J Anim Sci, 60, 1485-1490.

22. Kurt D, Denli O, Kanay Z, Güzel C, Ceylan $\mathbf{K}(2001)$ : Diyarbakar bölgesi Akkaraman koyunkarnda kan serumunda $C u, Z n$, Se ve yünde $C u$, Zn dïzeylerinin araşzulmast. Turk $J$ Vet Anim Sci, 25, 431-436.

23. Lamand M (1975): Les mineraux ef les vitumines. Point Vet, 1, 135-142.

24. Lorenz PP, Gibb FM (1975): Ceruloplasinin activity as in indication of plasma copper levels in sheep. NZ Vet J, 23. 1-3.

25. Marcos ER (1982): Valores poblacionales de parametros sanguineos, segun estado de lactancia y. epoca del. Ano Rev Med Vet, 63, 260)-278.

26. Mastens DG, Somers M (1980): Zinc ktatus of grazing sheep: Seasonal changes in zinc concentrations in plasma. wool and pastures. Austr J Exp Agr Anim Husb, 102, 2024.

27. McDowell LR (1992): Minerals in Animals and Human Nutrition. Academic Press, New York.

28. Murray RK, Granner DK, Mayes PA, Rodwell VW (1996): Harper's Biochemistry. 24 ${ }^{\text {th }}$ Ed. Appleton and Lange, USA. 
29. Ozan S (1985): Karacabey Merinos koyunlarmda yapağı dikiumü ile kanda çinko bakır düzeyleri arasinda ilişsiler. Selçuk Üniv Vet Fak Derg, 1, 133-142.

30. Salvin W (1968): Atomic Absorption Spectroscopy. Chemical Analysis, 25, 87-90)

31. Serpek B, Baspmar N, Soysal S (1989): Konya ili ve çepresinde yetistirilen koyunlarda hipokuprozis tanst ve tedanisi amactyla serum serüloplazmin konsantrasyonlarmin saptanmasi. İstanbul Üniv Vet Fak Derg, 15, 1-7.

32. SPSS Inc (1960): SPSS for Windows 9.3. Base System User's Guide. Release 9.0. Copyright 1998 by SPSS Inc. Printed in the USA.

33. Stahr HM (1991): Analytical Methods in Toxicology. A Wiley-Intersicenci Publication, John Wilcy and Sons Inc, New York

34. Sahin T (1999): Endoparazitli koyunlarda baż iz. elementler ve biyokimyasal parametrelerin seviyeleri üzerine araştımalar: Doktora tezi. YYÜ. Sağ Bil Enst, Van.

35. Şendil Ç, Bayşu N, Ünsüren H, Çelikkan M (1975): Yurdumužda enzootik ataksinin varlı̆̆g ve ensidanst üzerinde çallşmalar. Elazı̆̆ Vet Fak Derg, 2, 38-52.

36. Tiftik AM, Doğanay S (1997): Izmir bölgesi koyunlartnda kan serumu baker $(\mathrm{Cu})$, demir ( $\mathrm{Fe}$ ), total demir bağlama kapasitesi (TDBK) ve çinko $(Z n)$ diazeylerinin araşthrlınası. Vet Bil Derg, 13, 147-156.

37. Underwood EJ, Suttle NF (2000): The Mineral Nutrition of Livestock. $3^{\text {rd }}$ Ed. CABI Publishing, Edinburgh.
38. White CL, Martin GB, Hynd PI, Chopeman RE (1994): The effect of zinc deficiency on wool growth and skin and wool follicle histology of male Merino lambs. Br J Nutr, 71. 425-435.

39. Wiener G (1969): The concentration of minerals in the blood of genetically divers groups of sheep. I. Copper concentration at different seasons in blackface. Cheviot. Welsh Mountain and Crossbred sheep at pasture. J Agric Sci Camb, 72, 93-101.

40. Wildeus D, McDowell LR, Fugle JR (1992): Season and location effects on serum and liver mineral concentrations of senepol cattle on St Croix, Virgin Islands. Trop Anim Hith Prod, 24, 223-230.

41. Wong BS, Brown DR, Pan T, Whiteman M, Liu T, Bu X, Li R, Gambetti P, Olesik J, Rubenstein R, Sy MS (2001): Oxidative impaiment in scrapie-infected mice is associated with brain metals perturbations and altered antioxidant activities. J Neurochem, 79, 689-698.

Geliş tarihi: 2.4.2002/Kabul tarihi: 13.5.2002

\section{Yazışma adresi:}

Yrd. Doç: Dr. Suan Erdoğan

Mustafa Kemal Üniversitesi Veteriner Fakuiltesi. Biyokimya Anabilim Dal

31040 Antakyci/Hatay

E-mail:serdogan@mku.edu.r. 